\title{
EPIDEMIOLOGICAL STUDY OF HOMICIDE BY FIREARMS AND EXPLOSIVES
}

Rajeev Kumar ${ }^{1}$

\section{HOW TO CITE THIS ARTICLE:}

Rajeev Kumar. "Epidemiological study of homicide by firearms and explosives". Journal of Evolution of Medical and Dental Sciences 2013; Vol. 2, Issue 43, October 28; Page: 8419-8437.

ABSTRACT: BACKGROUND: Murderers have often been the focous of sociological and psychological studies and several types of offenders have been identified. OBJECTIVE: Epidemiological study of homicide by firearms and explosives. METHODS: The present study comprised of 100 (one hundred) cases of homicidal firearms and explosives deaths drawn from the medicolegal autopsies. The various data relating to the cases were collected from examination of inquest reports and connected papers, interviewing the police personnel accompanying the cases, interviewing the relatives, friends and neighbors of the deceased, and the autopsy examination paper. RESULTS: Two third( $66 \%$ ) of victims were normal followed by irritable victims $17 \%$, neurotic $8 \%$, psychotic $5 \%$ and intoxicated $4 \%$.It was found that $35 \%$ were pan eater followed by $30 \%$ who had no habit, cigarette $16 \%$ bidi $15 \%$, tobacco $14 \%$, pan masala $11 \%$.However misxed/combine habit was seen in $16 \%$ and it could not be known in $7 \%$. It was observed that that max no (52) of victims no drug habit was seen. This was followed by ganja 22, alcohol 16, Bhang 14, Opium 5, sleeping pill 2.Mixed drug habit was seen in 10 victim. However it could not be known in 12 victims. It was found that majority $57 \%$ of victims came from joint family followed by those from nuclear family type $28 \%$. However, $15 \%$ victims were loner. Findings on personal income of victims shows that max 37\% had income upto Rs. 2000 PM followed by non earning Victims 24\%, 2001$400015.1 \%, 8001$ and above 9\%, 4001-6000 8\%, 6001-8000(6\%) and in one \% it could not be known. Study shows that max 30\% victim were killed in night hours between 8 PM to 2AM followed by $25 \%$ in the afternoon and evening hrs between 2 PM to 8PM.16\% victims were attacked during day hrs between 8AM to 2PM and $12 \%$ victims time of incidence was between 2 AM to 8AM.Time of incidence could not be known in $17 \%$ victims as only dead body was recovered. It is observed that over majority 55\% victims were killed in the evening and night hrs between 2pm to 2 am. Findings on place of incidence clearly shows that majority $71 \%$ of incidents took place outdoors and $29 \%$ indoors. In outdoor location field was the place of incidence in $34 \%$ victims followed by farm $8 \%$ and garden which was the place of incidence in $6 \%$ victims. Only dead body was recovered in $10 \%$ cases.In indoor locations bedroom was the place incidence in $11 \%$ victims followed by corridoor in $7 \%$ victims and court yard in 4\% victims. Only dead body was recovered in $7 \%$ cases. CONCLUSION: Increase in use of firearms may be attributed to the deteriorating socioeconomic, and law and order situation and also easy availability of both licit and ilicit as well as improvised or country made firearms and bombs all over India.The ever expanding areas of individual and mass violence including political terrorism, communal violence, dacoities, smuggling across the inter national and state borders, kidnapping for ransome and hijacking of aircrafts have all contributed their share to the phenomenal rise in the use of firearm and explosives resulting in many homicidal deaths.

KEY WORDS: Epidemiological study, homicidal deaths. 
INTRODUCTION: Murder, is learned within the family and community in a larger society. It is a nonhuman behaviour which consists of an act that offends certain very strong, collective belief and sentiments. Often criminal tendencies and behaviour are generally close association with once own would be killer who share the value and accepts a common culture. Hence, homicide is a problem pertaining to relationship of the murder and victim, It often occur by sheer chance.

Homicide may be due to certain provocation on the part of the victim and / or uncontrollable impulsive emotion of the murderer, but impulsive behaviour does not force every body to committee criminal homicide. Every murderer, therefore, gradually and consciously or unconsciously accepts homicide as an absolute solution for problem he faces. Though homicide, in general seems universal, the type and pattern are specific to particular societies and particular times.

Murderers have often been the focus of sociological and psychological studies and several types of offenders have been identified. According to researches, most murders are committed by people who may be categorized as the normal or typical murderer, meaning that the offender is not characterized by marked psychopathology (Manfred Guttmacher. 1967).

Another type of murderer is the 'hit man', or professional murderer, the person who is hired is murder. Although we might understand the process by which someone drifts into a career of crime, kill during a heat of passion or associated with deviant and learns to accept their way of life, is possible for us to accept murder as a profession.

Mass and serial murderers are the typical types, but they are the most feared. Recently the media and the social scientists, have focused on the serial murderers. Murderer, often a driffer, who roams around and kills at random. In contrast the mass murderer kill people at once.

What do serial murders have in common? Authorities say sexual problem is a shared characteristics. Many of the violent, torture type murders have involved homosexual males. John wayne gacy, convicted in Illinois for slaying of thirty three young men, apparently had sexually molested most of them before they were strangled, their bodies were found in the crawl space of Gacy's home. Henry Less Lucas, a serial murderer, a driffer, who claims to have murdered 165 woman since he was thirteen, said the reason was sex. He said that he killed them because they refused to have sexual relation with him: he then had sex with the deceased victims, a practice, known as necrophilia (Reid, 1988).

The criminal- victim relationship is called 'Victimology' and considered as an integral part of criminology (Devasis and Devasia, 1989). Victim is not just a passive object but an active component of his or her own victimization. Victimology is the empirical, factual study of victims of crime and as such is closely related to criminology, and thus may be regarded as a part of the general problem of crime. In a broader sense Victimization and the efforts of society to preserve the rights of the victims.

Various theories of social interaction, have established the framework of the victim - offender relationship. In criminology literature, however, probably von henting (1948) in his study on the criminal and his victim had provided the most useful theoretical relationship where in he delebrated upon "the contribution of the victim to the genesis of crime" discusses this fact of crime and suggests that homicide is particularly amenable to analysis.

Mendelsohn (1976) considers victimology as science. For him it is a science of victims and victimity. So victimology can take into account all phenomena which cause victims " To actually 
practice Victimology, to make the research fit the name, it will be necessary to concentrate our attention on the central point, the essential factor common to all victims, of man, machinery, society and biological and social problems, etc.

For Schafer, the victims' importance reflects the offender's and victim's joint existence in victimization. "Crime should be seen in its functional dynamics. An all dimensional view of crime cannot accept the criminal's behaviour and the victims behaviour as two distint and separate forms of conduct. The victim is a part of crime, often playing an esoteric and not an exoteric role" (Schafer, 1976).

REVIEW OF LITERATURE: Various studies indicates the psychological orientation of individuals and throw light on their murderous behaviour. While many scholars underline the importance of the theory of victim precipitating the murder (Wolfgang, 1958). Comprehends that homicide involves intense personal interaction between the victim and the murderer. Savalastoga (1956), sills (1968), Clinard and Meir (1979), Prasad and Maheshwari (1986) emphasize the role of victims precipitating the murder.

During a study on murderers Duncan et al. (1959) reported that for those who committed these offences, physical brutality at the hands of the parents had been a constant experience. Hence, conditioned to physical torture, each of these individual eventually resorted to the technique that had been deeply impressed upon them.

McCord and McCord (1959) found a similar result with reference to the importance of brutality by the father in subsequent murderous behaviour.

Homicide may be due to sudden provocation on the part of the victim and/or uncontrollable impulsive emotion of the murderer, but impulsive behaviour does not force everybody to commit homicide (Devasia, 1992).

Homicide Rate (Incidence): Durkheim's (1893) theory of organic solidarity suggests a general reason for a positive effect of rurality on the homicide rate. Organic solidarity depends on dynamic density, and rurality depresses dynamic density. Findings by Messner (1982) indicates that the homicide rate tends to be high where organic solidarity is low, and finding in rural areas of the united states suggest that spatial dispersion of a local population impedes community integration (Wilkinson, 1982).

Cohan and Felson (1979) argue that the homicide rate is a function of the opportunities for victimization which is defined as the convergence of motivated offenders and suitable target in the absence of capable guardians because this convergence is expected to occur.More often people spend much time outside the home or away from family members, they predicted homicide rate will be higher where daily activities are more dispersed.

Several researchers have suggested that the higher rates of homicide in the south may be accounted for by subculture factors that distinguish southern population (Porterfield, 1949; Hackney, 1969) this perspective has been articulated most completely in the work of Gastil (1975, 1979) who believes that that "the evidence suggested that it is a predisposition to lethal violence in southern regional culture that accounts for the greater part of the relative height of the American homicide rate. 
A reanalysis of regional differences in homicide rate is conducted for two types of homicide, derived from the victim-offender relationship. A social structural, as apposed to subcultural, explanation is supported, but is found to have limitations. Social structural variables, particularly poverty, are shown to be important predictor of differences in primary homicide rates (generally involving family members or friends), but are less important in explaining variations in non-primary rate (those generally involving strangers) (Smith and Parker, 1980)

Homicide rates in western societies appears to have declined over the last several hundred years, but more recently, they experienced sharp and short term upsurges in the early 19th century and in the last two decades (Gurr. 1981)

Blau and Blau (1982) found that economic inequality both between and within rates, is a significant predictor of homicide rates across metropolitan areas. They suggested that economic inequality engender, alienation, despair and pent up aggression which find expression in frequent conflict including a high incidence of criminal violence.

The theoretical orientation of recent research on convariates of homicide rates are al so often informed by one or both perspectives on the effect of age the first perspective is based on long standing observation of a greater propensity for teenager and young adults to commit more crimes, than individuals at other ages and is most recently articulated by Hirschi and Gottfredson (1983).

The second perspective is articulated by Cohen and Land (1987) who noted that teenager and young adults not only commit crimes more frequently than those in other age groups but also are more likely to be victims. This preponderance is due to the participation of young persons in life styles at greater risk of victimization.

Massner (1989) argue that economic discrimination should have an appreciable effect on national homicide rate. Furthermore, the effect of discrimination should be greater then the effect of income inequality.

Two hypothesis are derived from Macro's structural theory concerning the relationship between economic discrimination and national homicide rates (1) level of economic discrimination should be positively related to national homicide rates (2) the level of economic discrimination should be a stronger predictor of homicides rates than income inequality.

\section{Epidemiological Aspects:}

Alcohol and Drug Habits: Wolfgang (1958) reported that in 64\% of the homicide situations alcohol was present either in the victims (9\%) or the offenders $(11 \%)$ or in both $(44 \%)$.

Welte et al. (1989) studied 792 cases of homicide victims during 1972 - 84 in New York. Logistic regression that there is a high likely hood of alcohol in the blood of victims in homicides that are associated with circumstances that make drinking more likely, e.g. occurrence at a bar or party, arise spontaneously from personal disputes, occur during time period when there are more homicide in general. It suggested that alcohol may be casual factor in some cases of homicide.

Lindqvist (1991) was especially concerned of homicides committed by abusers of alcohol and illicit drugs. He observed 52 abusers of alcohol and 19abusres of illicit drugs who had committed homicide, in which 23 individuals were found guilty of murder. He also found most of the victims were abusers themselves, who were (ex-) partners or acquaintances of the offenders and had been drinking with their killer. The homicide committed by abusers of illicit drugs were characterized by less intimacy and the offenders were often considerable younger than their victims. 
Roy (1994) found in his study of homicide victims at Varanasi 44.39\% victims were smokers, $31.70 \%$ were pan eater, $9.75 \%$ tobacco chewer, $9.75 \%$ drinker and $2.43 \%$ were drug addicts.

Occupation: Asuni (1969) in his study of homicide victims in West Nigeria concluded that to traditional group $40.38 \%$ victims were farmers or small land holders, followed by fisherman, laborer, petty traders (7.69\% each) and traditional healer whereas remaining $34.61 \%$ were nontraditional including motor drivers sawyears, cornmell operators, brick layerers and domestic stewards.

Subhramanyam et al. (1978) reported a high percentage of a agriculturists $50.0 \%$ and businessman $18.30 \%$ in their series of fatal firearm victims laborer (5.92\%) and students (4.30\%) and remaining $44.6 \%$ were dacoits, robbers, thieves and other antisocial elements.

Tosayanand (1984) revealed that over majority of victims $55.66 \%$ were employed in office and factories, followed by employed (17.85\%) and house wife (11.54\%), students (6.68\%), government officials and self employed (6.62\%) and $1.5 \%$ were children.

Nabachandra (1984) observed in their stubby that largest occupational group was farmer (30.14\%) followed by business and dacoits (14.63\% each) among the firearm homicidal victims of Varanasi.

Whereas, Santomba (1985) is his series of sharp weapon fatalities recorded $32.05 \%$ agriculturists, $25.51 \%$ laborers, $25.91 \%$ businessman, $7.6 \%$ housewives, $5.12 \%$ servicemen and $3.82 \%$ students as occupation.

Rai (1987) observed that largest occupational group among the victims of homicide by blunt weapon were agriculturists (35.29\%) followed by servicemen (16.47\%), labourer (14.12\%) household industries (8.24\%), businessman (7.06\%) and stu dents (4.71\%).

Chimbos (1993) while analyzing the occupation of offenders and victims of homicide found that $73 \%$ of the offenders and $46 \%$ of the victims whose occupation were known to news reporters came from these occupational categories. Persons who were not employed, disable or minors comprised $15.4 \%$ of the offenders and $28.6 \%$ of the victims.

Similarities in the socio-economic background of homicide offenders and their victims have been reported by many researchers in other countries including the United States (Wolfgang, 1958; Manford et al., 1976) and Canada (Jayawardene, 1975; Chimbos, 1978).

At the same time above study show that the percentage of the victim $(17 \%)$ in the professional, managerial and business properties categories is higher than that of offenders (6.3\%). A possible explanation for this variation is the occurrence of political assassinations and robbery related homicide of small businessmen. The relatively high percentage (28.6\%) of victims among persons who were not employed reflects homicides against the Greek elderly during burglary or robbery.

Roy (1994) found overall number of homicidal victims involved in agriculture occupation were highest (36.58\%) followed by the business community (17.07\%), labourer (12.68\%), service people (7.31\%), student (6.82\%), house wife (6.46\%) and unemployed (2.92\%).

Income: Means of livelihood, economic resources or income have always been important to t he individual and group and in interpersonal and intergroup relations. They have become more so important in contemporary time characterized by what is termed as 'consumerism'. 
Krishna (1981) observed that the incomer pattern of the homicide victims in Delhi and Bangalore was to be markedly different. Victims in Bangalore were having a lower monthly income that those in Delhi. Victims belonging to middle age group and having a better educational status were having a higher income.

Motives: Vosa and Hepburn (1968) in a series of 394 homicide. The remaining cases revealed that an altercation over liquor money or a trivial matter such as insult or curse were the common motives allegedly involved underlying the deaths in over majority $(62 \%)$ of cases, while $33.9 \%$ of the white male victims were killed in robberies. The motive remained undermined in 28 (7.1\%) cases victims.

In Richard Block's (1975) study the number of robbery related homicides increased from 33 in 1965 to 162 in 1973 i.e. from 8\% to 19\% of all the homicides. The same study reveled essentially two patterns of homicides i.e one of the alteration homicides based on domestic fends or arguments between friends and the other based on robberies.

Subrahmanyam et al. (1978) studied the circumstances and the motives underlying 92 cases of firearm fatalities found that dispute over landed property was responsible in $24.39 \%$ cases, dacoity in $23.17 \%$ and robbery in $14.63 \%$ of the cases. Group rivalry was the motive behind $18.29 \%$ homicides and there was police-dacoit encounter in $2.43 \%$ of the case.

Gupta et al. (1979) in their series of 82 homicidal firearm, fatalities found that 35 cases involved dacoits and robberies, $9(10.11 \%)$ group rivalries, 8 (8.98\%) communal riots, $13(14.60 \%)$ disputes over landed properties, 15 (16.85\%) police encounters and 2 (2.24\%) cases over family feuds.

Das Gupta et al. (1983) studied the motives behind homicides in 372 homicidal cases and found that most of the homicides were committed for the motives of group rivalry followed by quarrel over landed properties, money and animals, mainly in the rural areas in 153 (41.12) cases, considerations for personal gains, such as dacoity, robbery and theft constituted the other major underlying motives (67 or 18.01\%). Police encounter, family fend, personal rivalry and heat of the moment constituted other significant motivation factors.

Locations or place of Incidence: In Pokorny's (1965) study of 419 homicide victims, 41.9\% occurs in the home and $58.1 \%$ outside the home, out of which $13.8 \%$ took place in bedroom, $3.6 \%$ in kitchen, $7.6 \%$ in living room, $26.1 \%$ in highways and $3.6 \%$ cases in other commercial places.

Of the 1392 victims of homicidal firearm deaths reported by Faltch et al. (1974), determination of location of shooting was possible in only 666 cases (51.54\%) out of which 355 (53.30\%) occurred inside and $40(6 \%)$ outside the private houses while $91(13.66 \%)$ case s took place at such places as bars, night clubs and poolrooms, $15(2 \%)$ at the service stations, $19(2.8 \%)$ at the victim's place of work and the remaining 127 (19.06\%) at miscellaneous places that included church and cemetery.

Out of the 82 homicidal firearm fatalities studied by Gupta et al. (1979), 47 cases occurred in the homes and 35 cases on fields and roads.

Hour of the Day and Month of the Year of Incidences: Wolfgang (1958) studied 588 homicidal victims and found that maximum (49.7\%) of the victims were killed between 8 P.M. to 1.59 A.M., 
$24.7 \%$ between $2 \mathrm{PM}$ to $7.59 \mathrm{PM}, 16.5 \%$ between $2 \mathrm{AM}$. To $7.59 \mathrm{AM}$. and the rest $9.2 \%$ victims were killed between 8 AM. to 1.59 PM.

Pokorny (1965) studied 409 homicidal victims and his findings were more or less the same as those of Wolfgang. He reported 49.9\% incidence occurring between 8 PM to 1.59 AM. 27.9\% between $2 \mathrm{PM}$ to $7.59 \%$ and the rest $22.2 \%$ between $2 \mathrm{AM}$. to $1.59 \mathrm{PM}$. The study also revealed that the hours during which homicides occurred with the greatest frequency was between 8 PM. and midnight.

Gupta et al. (1979) analysed 82 homicidal firearm fatalities and showed that 38 (46.34\%) incidents occurred during the summer months between March to June followed by (26 or 31.7\%) during the rainy reason - July to October and the remaining 18 (21.9\%) cases occurred during the winter season November to February. He also observed that maximum number of incidents ( 40 or $48.78 \%$ ) occurred during midnight to 6 AM., followed by (32 or 39\%) cases during 6 PM to midnight and the rest $10(12.19 \%)$ cases occurrence between 6 AM. to 6 PM.

\section{MATERIAL AND METHODS:}

Material: The present study comprised of 100 (one hundred) cases of homicidal firearms and explosives injuries drawn from the medicolegal autopsies held in the mortuary of the department of Forensic Medicine, Institute of Medical Sciences, Banaras Hindu University, Varanasi, U.P., India, during the period from 1st July 1999 to $30^{\mathrm{M}}$ Nov. 2000, accompanied by sufficient number of relevant persons who were thoroughly interviewed at the time of autopsy on the body of deceased victim of homicide by firearm and explosives.

For the study relevant questionnaires schedule were prepared to collect various data, Socioeconomic factors, data about incidence of fatal firearm and explosive death, data about medicolegal crime investigation and evidential data etc. These cases were studied for the history of the cases, their epidemiological characteristics eg. age, sex, community character etc. nature, distribution and types of injuries including their medicolegal aspects.

Methods: The various data relating to the cases were collected from sources as under :
a. examination of inquest reports and connected papers.
b. interviewing the police personnel accompanying the cases.
c. interviewing the relatives, friends and neighbors of the deceased, and
d. the autopsy examination paper.

The various data pertaining to each case was collected by the methods as indicated above so as to provide information on the following points :

1. History as regard s date, time and place

2. Epidemiological features

\section{A. In Regard to Victims}
a. Age,
b. Sex,
c. Religion/caste,
d. Community character, Rural/urban/suburban.
e. Educational status, 
f. Physical status

g. Marital status

h. Mental status

i. Personal habits

j. Drug habits

k. Personal hobby

(i) Indoor

(ii) Outdoor

l. Dependents

m. Family type

n. Occupational status

o. Family occupation

p. Income

(i) Personal \&

(ii) Family

q. Apparel

r. Activity at the time of incidence

s. Position at the time of incidence

t. What did victim do after receiving the injury

u. Whether victim required medical care or not and was operated or not after sustaining the injury,

v. Whether any other person was injured

w. Who first saw the victim and who informed to the police about the incidence

$\mathrm{x}$. Condition of victim on arrival of police

y. Whether the police recovered the victim alive/dead

\section{Environmental Data}

a. Date and time of incidence

b. Place of incidence

(i) Indoor

(ii) Outdoor

c. Whether empty cartridge, shots, pellets etc. were recovered from the scene.

OBSERVATION AND RESULTS: In the present study, a total of 100 cases of homicide by firearm and explosives drawn from the medicolegal autopsies of Varanasi area including Chandauli carried out in the memory od Department of Forensic Medicine of Institute of Medical Sciences, Banaras Hindu university, Varanasi, During the period from 1.7.99 to 30.11.2000 (17 months).

\begin{tabular}{|c|c|}
\hline Mental status & Percentage \\
\hline Normal & 66 \\
\hline Irritable & 17 \\
\hline Neurotic & 8 \\
\hline Psychotic & 5 \\
\hline
\end{tabular}




\section{ORIGINAL ARTICLE}

\begin{tabular}{|c|c|}
\hline Intoxicated & 4 \\
\hline \multicolumn{2}{|c|}{ Table 1: Mental status of homicide } \\
by firearm and explosives.
\end{tabular}

Table given shows that two third $66 \%$ of victims were normal followed by irritable victims $17 \%$, neurotic $8 \%$, psychotic $5 \%$ and intoxicated $4 \%$.

\begin{tabular}{|l|c|}
\hline \multicolumn{1}{|c|}{ Habits } & Percentage \\
\hline No habit & 30 \\
\hline Bidi & 15 \\
\hline Pan & 35 \\
\hline Cigarette & 16 \\
\hline Tobbaco chewing & 14 \\
\hline Pan masala (gutkha) & 11 \\
\hline Mixed & 16 \\
\hline Not known & 7 \\
\hline
\end{tabular}

Table 2: Personal habits of homicide

by firearm and explosives.

Above given table on personal habit of the victims shows that max $35 \%$ were pan eater followed by $30 \%$ who had no habit, cigarette $16 \%$ bidi $15 \%$, tobacco $14 \%$, pan masala 11\%.However missed/combine habit was seen in $16 \%$ and it could not be known in $7 \%$

\begin{tabular}{|l|c|}
\hline \multicolumn{1}{|c|}{ Drug } & Percentage \\
\hline No Drug Habit & 52 \\
\hline Alcohol & 16 \\
\hline Ganja & 22 \\
\hline Bhang & 14 \\
\hline Opium & 5 \\
\hline Sleeping Pills & 2 \\
\hline Mixed & 10 \\
\hline Unknown & 12 \\
\hline Table 3: Drug habits of victims \\
\multicolumn{2}{|c|}{ of homicide } \\
by firearm and explosives. \\
\hline \multicolumn{2}{|c|}{}
\end{tabular}

Table shows that max no 52 of victims no drug habit was seen. This was followed by ganja 22, alcohol 16, Bhang 14, Opium 5, sleeping pill 2.Mixed drug habit was seen in 10 victim. However it could not be known in 12 victims. 


\begin{tabular}{|c|c|}
\hline Family type & Percentage. \\
\hline Joint & 57 \\
\hline Nuclear & 28 \\
\hline Loner & 15 \\
\hline & 100 \\
\hline
\end{tabular}

Table 4: Family type of victims of homicide

by firearm and explosives.

Table given above on family type of victims clearly show that majority $57 \%$ of victims came from joint family followed by those drom nuclear family type $28 \%$. However, $15 \%$ victims were loner.

\begin{tabular}{|c|c|}
\hline Income in Rs.PM & Percentage \\
\hline Upto 2000 & 37 \\
\hline $2001-4000$ & 15 \\
\hline $4001-6000$ & 8 \\
\hline $6001-8000$ & 6 \\
\hline 8001 and above & 9 \\
\hline Non earning & 24 \\
\hline Not known & 1 \\
\hline
\end{tabular}

Above table on personal income of victims shows that max 37\% had income upto Rs. 2000 PM followed by non earning Victims 24\%, 2001-4000 15.1 \%, 8001 and above 9\%, 4001-6000 8\%, $6001-8000(6 \%)$ and in one $\%$ it could not be known.

\begin{tabular}{|l|l|}
\hline Family income in Rs.PM & Percentage \\
\hline Up to 2000 & 44 \\
\hline $2001-40000$ & 18 \\
\hline $4001-6000$ & 10 \\
\hline $6001-8000$ & 8 \\
\hline 8001 and above & 11 \\
\hline Non earning & 8 \\
\hline Not Known & 1 \\
\hline $\begin{array}{l}\text { Table 6: Family income of victims of } \\
\text { homicide by firearms and explosives. }\end{array}$ \\
\hline
\end{tabular}

Table on family income of victims clearly shows that the family income of max $44 \%$ victim was up to Rs.2000 PM. Followed by those having 2001-4000 $18 \%, 4001-6000$ (10\%), 6001$8000(8 \%), 8001$ and above 11\%. Family income of 8\% victims were nil. However, it could not be known in $1 \%$ Victims.

\begin{tabular}{|l|l|l|l|}
\hline \multicolumn{1}{|c|}{ Economic } & \multicolumn{1}{|c|}{ Family related } & Other & Not known \\
\hline Quarrel over & Enemity and & Police encounter-6 & \\
\hline
\end{tabular}




\section{ORIGINAL ARTICLE}

\begin{tabular}{|c|c|c|c|}
\hline Landed property-40 & Revenge-14 & & \\
\hline Dacoity-14 & & Group Rivalry-5 & \\
\hline $\begin{array}{l}\text { Quarrel over } \\
\text { Income distribution - 4 }\end{array}$ & $\begin{array}{l}\text { Quarrel over husband and } \\
\text { wife relationship-3 }\end{array}$ & Damage to prestige -3 & \\
\hline $\begin{array}{l}\text { Quarrel over movable } \\
\text { Property -3 }\end{array}$ & $\begin{array}{l}\text { Quarrel over } \\
\text { Household work-2 }\end{array}$ & & 1 \\
\hline \multicolumn{4}{|l|}{$\begin{array}{l}\text { Robbery and } \\
\text { Theft-5 }\end{array}$} \\
\hline 66 & 19 & 14 & 1 \\
\hline Total & 100 & & \\
\hline
\end{tabular}

Above given table on motives of homicide clearly depict that economic causes were the motive in over majority $66 \%$ of victims followed by family related causes $19 \%$ and other causes in $14 \%$ of victims. It was not known in one victim.

It in further seen that quarrel over landed property was the accuses in $40 \%$ victims, Dacoity in $14 \%$, Quarrel over income distribution in $4 \%$ victims. Quarrel over movable property 3\% and robbery was seen in 5\% victims. Enemity and revenge was responsible in $14 \%$. Police encounter was seen in $6 \%$ victims of homicide in firearm and explosives. Group revelry 5\% damage to prestige $3 \%$. It was not known in one victim.

\begin{tabular}{|l|c|}
\hline \multicolumn{1}{|c|}{ Time of incidence } & Percentage \\
\hline 8 PM to 2 PM & 30 \\
\hline 2 AM to 8 AM & 12 \\
\hline 8AM to 2 PM & 16 \\
\hline 2PM to 8 PM & 25 \\
\hline Not known & 17 \\
\hline \multicolumn{2}{|c|}{ Table 8: Time of incidence of } \\
homicide by firearm and explosives.
\end{tabular}

Table given shows that max 30\% victim were killed in night hours between 8 PM to 2AM followed by $25 \%$ in the afternoon and evening hrs between 2 PM to 8PM.16\% victims were attacked during day hrs between 8AM to 2PM and $12 \%$ victims time of incidence was between $2 \mathrm{AM}$ to 8AM.Time of incidence could not be known in $17 \%$ victims as only dead body was recovered. It is observed that over majority 55\% victims were killed in the evening and night hrs between $2 \mathrm{pm}$ to 2 am.]

\begin{tabular}{|l|l|}
\hline \multicolumn{1}{|c|}{ Indoor } & \multicolumn{1}{c|}{ Outdoor } \\
\hline Bed Room-11 & Fiels-34 \\
\hline Corridor-7 & Farm \\
\hline Courtyard-4 & Road side-2 \\
\hline Only dead body recovered-7 & Hotel and restaurant campus-5 \\
\hline & Garden-6 \\
\hline
\end{tabular}




\section{ORIGINAL ARTICLE}

\begin{tabular}{|c|l|}
\hline & Near wine shop-6 \\
\hline & Only dead body recovered-10 \\
\hline 29 & 71 \\
\hline Table 9: Place of incidence in homicide by \\
firearm and explosives.
\end{tabular}

Table on palace of incidence clearly shows that majority $71 \%$ of incidents took place outdoors and $29 \%$ indoors.

In outdoor location field was the place of incidence in $34 \%$ victims followed by farm $8 \%$ and garden which was the place of incidence in $6 \%$ victims. Only dead body was recovered in $10 \%$ cases. In indoor locations bedroom was the place incidence in $11 \%$ victims followed by corridor in $7 \%$ victims and court yard in $4 \%$ victims. Only dead body was recovered in $7 \%$ cases.

\begin{tabular}{|l|c|}
\hline & Percentage \\
\hline Fired through clothed part with wound of entry only & 25 \\
\hline Fired through clothed part with wound of entry and exit. & 30 \\
\hline Hospitalised victims where wearing apparels were removed. & 23 \\
\hline Fired through unclothed part & 35 \\
\hline Clothings torn to pieces due to bomb explosion. & 12 \\
\hline
\end{tabular}

Table 10: Wearing apparel of victims of homicide by firearms and explosives.

Table shows that max 35\% victims firing was through unclothed part followed by firing through clothed part with wound of entry and exit 30\%.In $25 \%$ Victims firing was through clothed part with wound of entry only.In 23\% victims wearing apparels were removed in hospital and in 12 $\%$ victims clothing were torn to pieces due to bomb explosion.

DISCISSION: For the present study, a total of 100 cases of homicide by firearms and explosives were taken from the medico logy autopsies of Varanasi area that were carried out in the mortuary of department of forensic medicine, Institute of medical sciences, Banaras Hindu University, Varanasi during the period from $1^{\text {st }}$ July 1999 to $30^{\text {th }}$ Nov 2000. These were studied and analyzed with special reference to their epidemiological and medico legal aspects. 


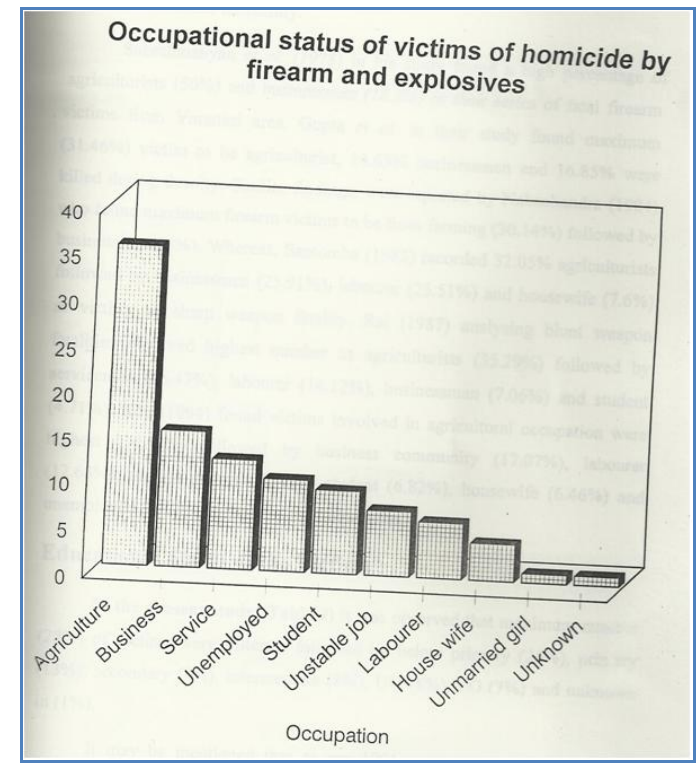

Lasting so much so that even in courts, litigation continue over generations and sporadic criminal clashes occurs between the parties leading to homicidal victimization more frequently.

Subrahmanyan et al. (1978) in his study found a high percentage of agriculturists (50\%) and businessmen $(18.3 \%)$ in their series of fatal fiream victims from Varanasi area Gupta et al. in their study found maximum (31.46\%) victim to be agriculturist, 14.63 businessmen and $16.85 \%$ were killed during dacoity. Similar findings, were reported by Nabachandra (1984) who found maximum fiream victims to be from farming (31.14\%) followed by business $(14.63 \%)$. Whereas, Santomba (1985) recorded $32.05 \%$ agriculturists followed by businessmen (25.91\%), labourer (25.51\%) and housewife (7.6\%) as victims of sharp weapon fatality. Rai (1987) analyzing blunt weapon fatalities observed highest number as agriculturists (35.29\%) followed by servicemen $(16.47 \%)$ labourer (14.12\%) businessman (7.06\%) and student (4.71\%). Roy (1994) found victims involved in agricultural occupation were highest $(36.58 \%)$ followed by business community $(17.07 \%)$, labourer (12.68\%), Service people (7.31\%), student (6.82\%), housewife (6.46\%) and unemployed (2.42\%) in descending frequencies.

Family Type of Victims: Forms our study (Table 14) on type of family or homicidal victims it is noted that the majority of victims (57\%) came from joint families followed by those from (28\%) nuclear family and loner (15\%).

The incidence of over majority (57\%) of homicide in joint families is comparable with our findings of more victims from rural population where joint family system is more common. In joint family, besides many benefits, there are many problems as well as economy which may lead to disproportionate distribution of rewards for colour to individual member in same family. Whether, or not a member is working may not necessarily correlate with the privileges he gets, which may be important cause of growing frustration among members of the family. Large family size also envisage more needs and its fulfillment unbalanced. With the growing generation it becomes more and more difficult to centralize power and economy and when they divide, divide with the seeds of 
enemity amongst themselves making one or the other group victimized depending upon their strength.

Motives of Homicide by Firearms and Explosives: In our study (Table17) it is noted that in as much as $40 \%$ cases, motive was quarrel over landed property followed by dacoity (14\%), enemity and revenge ( $14 \%$ ), police encounter ( $6 \%$ ), group rivalry ( $5 \%$ ) robbery and theft $(5 \%)$ quarrel over movable property (3\%), over husband wife relationship (3\%) damage to prestige (3\%) and household work ( $2 \%$ ), Broadly speaking economic cause was the motive in $66 \%$, family related cause $19 \%$ and other causes in $14 \%$.
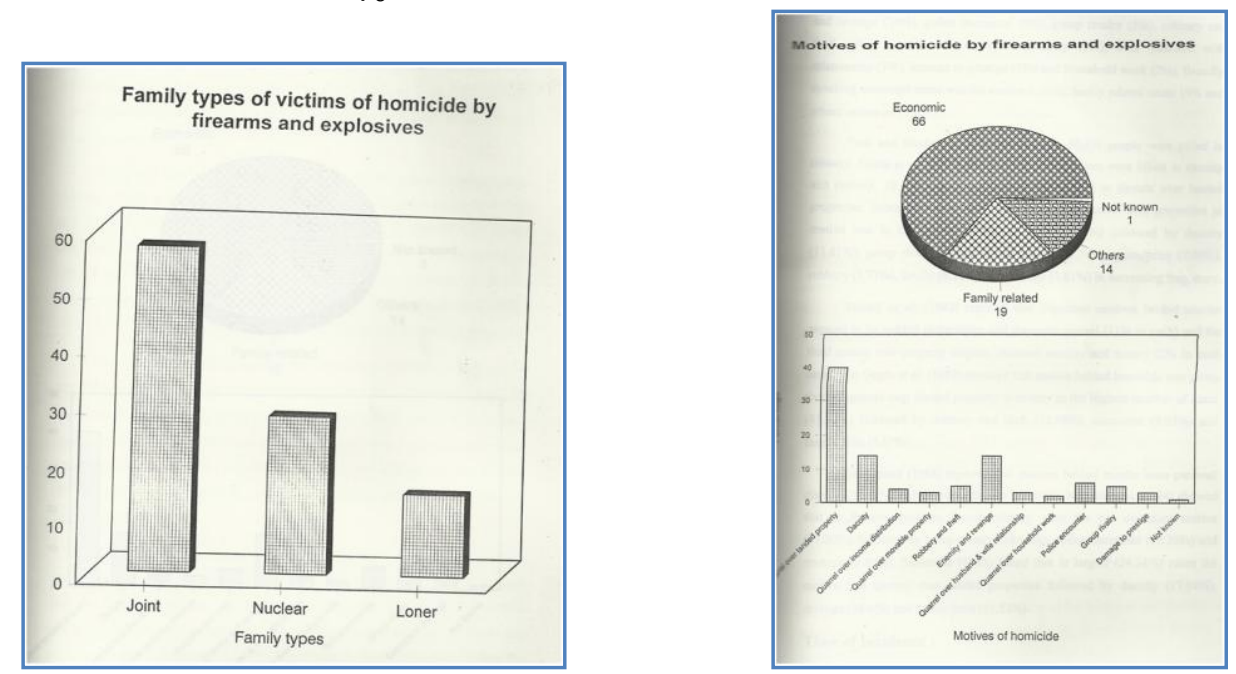

Voss and Hepbum (1968) revealed that 30.9\% people were pilled in robbery. Gupta et al. (1979) reported that $35 \%$ victims were killed in dacoity and robbery, 10.11 due to group rivalries, 14.60 in dispute over landed properties. Subramanyam et al. (1978) found that quarrel over properties as motive was in the largest number of cases $(29.3 \%)$ followed by dacoity (11.61\%), group rivalry $(10.96 \%)$, old enemity $(7.74 \%)$, goondaism $(7.09 \%)$, robbery $(7.77 \%)$, family $(6.12 \%)$ and revenge $(3.81 \%)$ in decreasing frequency.

Trivedi et al. (1982) reported that important motives behind murder seemed to be marital disharmony and domestic quarrel (11\% in each ) and the third reason was property dispute, personal enemity and lunacy ( $2 \%$ in each case). Das Gupta et al. (1983) revealed that motive behind homicide was group rivalry, quarrel over landed property or money in the highest number of cases (41.12\%) followed by robbery and theft (15.88\%), encounter (8.03\%) and family feud (5.67\%).

Tosayanand (1984) reported that motives behind murder were personal dispute (26.92\%) and property dispute $(11.54 \%$ ) Nabachandra (1984) showed that in firearm fatalities dacoity / robbery were the pre dominant motive $(37.80 \%)$ followed by group rivalry (14.63\%), police encounter $(12.20 \%)$ and revenge $(9.80 \%)$, Santomba (1985) found that in largest $(24.34 \%)$ cases the motive was quarrel over landed properties followed by dacoity $(17.94 \%)$, revenge (16.6\%) and family feud $(11.53 \%)$.

Time of Incidence: In our study (Table 18) it was noted that the highest number (30\%) of incidences took place between 8 PM to 2 AM followed by those that occurred between 2 PM to 8 PM (25\%), between 8 AM to 2 PM (16\%) and 2 AM to 8 AM (12\%), However, time of incidence could not be known in $17 \%$. Thus over majority (55\%) of victim were killed between 2 PM to $2 \mathrm{AM}$. 


\begin{tabular}{|l|l|l|l|}
\hline Time of incidence & Houston & Philadelphia & Varanasi Present study \\
\hline 8 PM to 2 AM & 49.9 & 49.7 & 30.0 \\
\hline 2 AM to 8 AM & 10.5 & 46.5 & 12.0 \\
\hline 8 AM to 2 PM & 11.7 & 9.2 & 16.0 \\
\hline 2 PM to 8 PM & 27.9 & 24.7 & 25.0 \\
\hline \multicolumn{4}{|c|}{ Table 8A : (in per cent ) } \\
\hline
\end{tabular}

In all the three series the highest number of homicide took place between 8 PM to $2 \mathrm{AM}$ (49.9\%, 49.7\% and 30.0\% respectively) followed by those occurring between 2 PM to 8 PM (27.9\%, $24.7 \%, 25 \%$ respectively). The number of fatalities in each series were comparatively less during the hours between 2 AM to 2 PM in all three series i.e. $22.2 \%, 25.7 \%$ and $28 \%$ respectively in Houston, Philadelphia and Varanasi series. In the light of above facts it would be interesting to study the factors behind this peculiar identity or relationship to the timing of homicidal fatalities that has emerged from a comparative study of the timing of the incidence of the cases in the above three series inspite of the widely varying geographical and socio-economic condition, prevailing between India and USA.

The incidence of a heinous crimes like homicide were commonly done in the dark hours of evening and night, perhaps due to the reasons the culprits could more safely execute the crime and escape. It is also more certain that in the evening and night hours the victim would be available at a premeditated place and chance of failure of find the victims at the known or pre mediated place during these hours are relatively least. Further the concealment of crime could be done safely during the late evening and night hours.

Our findings are in accordance with findings of many other researchers. In his study Wolfgang (1958) showed that majority (49.7\%) of victims were killed between 8 PM to 1.59AM. Pokorny (1965) also reported that a majority (49.9\%) of victims were killed between 8 PM to 1.59AM. while Asuni (1969) reported that maximum, number of homicide victims (37.38\%) were killed in night hours. Fattech et al. (1974) in their series of homicide by firearm found that over majority (55\%) of the victims were murdered between 8 PM to 4 PM. Of night hours and according to Muscat et al. (1991), the time of incidence of homicide more frequently (60\%) occurred between $4 \mathrm{PM}$ to $4 \mathrm{AM}$.

Place of Incidence in Homicide by Firearm and Explosives: In our study (Table 19) it was observed that over two third (71\%) of the fatal homicidal episodes took place at outdoor locations as against $29 \%$ that occurred at indoor places. Outdoor locations included field (34\%), farm (8\%), road side $(2 \%)$ hotel and restaurant campus (5\%) garden $(6 \%)$ near wine shop (6\%), Indoor locations included bedroom (11\%) corridor (7\%) court yard (4\%).

Outdoor places are more commonly selected for committing murder as the victims are more exposed and unprotected at outdoors and thus more vulnerable. At outdoor places victims could provide less resistance by himself or by other near and dear who are generally not present at outdoor places as compared to indoor places.

The observation of Pokorny (1965) also revealed that 58\% of victims were killed outdoor and $41.9 \%$ in indoor. Asuni (1969) in his study of homicide victims concluded that $41.5 \%$ cases occurred outdoors as against only $32 \%$ cases that occurred indoors. 
Nabachandra (1984) in their study showed that $58.54 \%$ of the firearm fatalities took place at outdoor places as against only $41.56 \%$ cases at indoor locations. Rai (1987) reported that overwhelming majority of homicide by blunt weapon $(74.12 \%)$ took place at outdoors, as against that occurred indoors (22.35\%). Roy (1994) also found that about two third (62.90\%) victims were killed at outdoor location and rest $37.10 \%$ at indoor location in Varanasi area.

However, Wolfgang (1958) Voss (1968) and Gupta et al. (1979) in their studies reported that indoors were the more frequent locations for homicide.

Wearing Apparel of Victims of Homicide by Firearms and Explosives: In our study (Table 20) it was recovered that in maximum (35\%) victims firing was through unclothed part followed by firing through clothed part with wound of entry and exit in 30 per cent and firing through clothed part with wound of entry only in 25 per cent. In as much as 23 per cent victims wearing apparels were removed in hospital and in 12 per cent victims clothing were torn into pieces due to bomb explosion.

In the series of Gupta et al. (1979) as much as $59.55 \%$ of the victims sustained entry wounds alone through clothed parts against $25 \%$ of the present series and while 32.58 of their cases sustained both entry and exit wounds through the clothed parts, the corresponding number was $30 \%$ in our series. But as much as $35 \%$ of our victims were fired through unclothed parts, only $7.86 \%$ cases were so fired in the series of Gupta et al. While these variations in the two series cannot be easily accounted for being from the same geographical area, except perhaps by way leaving them to sheer chances. It may be noted that all the three suicidal victims in the series of Gupta et al. (1979) fired upon themselves through unclothed parts. In as much as 23 per cent of our cases it could not be ascertained if the shots, whether entry or exit or both, were fired through the clothed or bare parts of the body, since the original wearing apparels were already removed in these hospitalized victims.

In Nabachandra's series firing took place through the clothed parts with wound of entry alone in $13.42 \%$ cases and with both entry and exit wounds in $14.63 \%$ of the victims, while as many as $41.46 \%$ cases firing was through the unclothed parts.

SUMMARY AND CONCLUSIONL: One hundred cases of homicide by firearm and explosive drawn from the medicolegal autopsies brought to the mortuary of Department of Forensic Medicine, Institute of Medical Sciences, Banaras Hindu University, Varanasi, U.P. India during the period from 1stJuly, 1999 to 30th November 2000, were studied for a detailed epidemiological and medicolegal analysis. The important highlighting findings of the study are summarised as under:

1. Mental status of over two third (66\%) of victims were normal.

2. Over one third (35\%) of victim of homicide by firearm and explosive were pan eaters and 30 per cent victims had no personal habit.

3. Over majority (52\%) of victims of homicide by firearm and explosive had no drug habit.

4. Family type of over majority of victims (57\%) was joint followed by nuclear.

5. Personal income of over one third (37\%) victims were upto Rs. 2000 per month.

6. Family income of maximum victims (46\%) were upto Rs. 2000 per month.

7. Motives behind homicide by firearm and explosive were quarrel over handed property in maximum cases $(40 \%$ ) and dacoity in 14 per cent cases.

8. Highest number of the homicidal firearm and explosive deaths took place between 8 PM to 2 AM (30\%). 
9. Over low third (71\%) incidences of homicide by firearm and explosive took place at outdoor places.

CONCLUSION: There has been a phenomenal rise in the use of firearms and explosives for committing various crimes leading to death of victims. This spurt in its use may be attributed to the deteriorating socio-economic, and law and order situation as also easy availability of both licit and illicit as well as improvised or country made firearms and bombs all over India.

The ever expanding areas of individual and mass violence including political terrorism, communal violence, dacoities, smuggling across the international and state borders kidnapping for ransom and hijacking of aircrafts have all contributed their share to the phenomenal size in the use of firearm and explosives resulting in many a homicide fatalities. Hardly a day passes in the life of a Forensic Pathologist working in one of the autopsy centres mainly in the northern part of India including Varanasi area, where he is not required or called upon to perform medicolegal autopsy examination on a victims of alleged death from firearm discharge.

But in view of the complexities created by the introduction of newer and newer improvised and conventional firearms and explosives in most of the a reas, the establishment of various facts in a cases of firearm death, such as the type of weapon used, the range of firing, the direction of fire, the number of shots fired, wound of entry and exit and the damage to vital parts and the like, have become fraught with serious and many fold difficulties/complexities for the Forensic Pathologists as also of the Ballistics.

\section{BIBLIOGRAPHY:}

1. Bureau of Police Research and Development (1983): Ministry of Home Affairs. Govt. of India, III.

2. Cameron, J.M. (1974): Changing Pattern of Violence. Med. Sci. Law. 13(4):264.

3. Cardarell, Albert P. (1968): An analysis of police killed by criminal action, 1961-63. Jr. Crim. Law and Criminology. 59(3):447-453.

4. Chandra, J., Dogra, T.D. and Dikshit, P.C. (1986): Comprehensive Study of Homicide in South Delhi.

5. Chao, T.C. (1973): Homicides an Suspected Homicides in Singapore. Med. Sci. Law. 13(2):98-108.

6. Chara, C.E. (1976): Fundamentals of Criminal Investigation $4^{\text {th }}$ Edn., $2^{\text {nd }}$ Printing Charles Thomas, pp. 761-778.

7. Chimbos Peter D. (1993): A Study of Patterns in Criminal Homicides in Greece. Ind. J. Criminology. 34(3-4):262-671.

8. Copeland Arthur, R. (1989): Multiple Homicide. American J Forensic Med. Path. 10(3):206-208.

9. Crime in India (1978): Bureau of Police Research and Development. Ministry of Home Affairs Government of India.

10. Crime of India (1979): Bureau of Police Research and Development, Ministry of Home Affairs, Govt. of India.

11. Crime of India (1986): National Crime Records Bureau. Ministry of Home Affairs. Government of India.

12. Crime of India (1993): National Crime Records Bureau. Ministry of Home Affairs. Government of India.

13. Crime of India (1994): National Crime Records Bureau. Ministry of Home Affairs. Government of India. 
14. Das Gupta S.M. and Tripathi C.B. (1983): A Study of the Homicide Cases Occurring in Varanasi Area. Indian Medical Gazette. CXVII(9):285-288.

15. Devasia, Leelamma and Devasia, V.V. (1989): Female Criminals and Female Victims, Nagpur: Dattsons.

16. Devasia, V.V. (1985): The Phenomenon of Criminal Homicide. Indian J. Criminology and Criminalistics, 12.

17. Devasia, V.V. and Devasia, L. (1985): The Phenomenon of Criminal Homicide. Indian J. Criminology and Criminalistics. 3-4:142-146.

18. DiMaio J.M., Jones J.A., Anderson L. and Petty C.S. (1974): Comparison of Wounding Effects of Commercially Available Handgun Ammunition. Law Enforcement Bull. 3:8.

19. DiMaio V.J.M. and DiMaio D.J. (1972): Bullet Embolism Six Cases and a Review of the Literature. J. For. Sci. 17:394.

20. DiMaio V.J.M. and Spitz, W.U. (1972): Variations in wounding due to unusual firearm and recently available ammunition. J. Forensic Sci. 17:377.

21. Durkheim, E. (1897); Le, Suicide, Paris: Felix Alcon. Quoted by Lester D. (1992). Can there be a Durkheimian Theory of Homicide? Indian J. Criminology. 20(2):

22. Durkheim, E.A. (1893). The Division of Labour in Society. Translated by G. Simpson Free Press, 1933.

23. Gordon I. and Shapiro, H.A. (1973): Forensic Medicine A Guide to Principles: Firearm Wounds. Chapter 13, pp. 292-306.

24. Govt, of India Ministry of Law (1967): The Probation of Offenders Act, 1958, Government of Indian Press, Delhi.

25. Gupta A.K., Das Gupta S.M. and Rastogi B.L. (1979): Study of Injuries from Firarm in Medicolegal Autospies. Thesis Submitted for the Degree of Doctor of Medicine (Forensic Medicine), Institute of Medical Science, B.H.U., Varanasi.

26. Hatcher J.S. (1935): Test Book of Pistols and Revolvers : Small and Technical Publishing Co., U.S.A. Chapter XV, pp. 315.

27. Hatcher J.S., Jury F..J. and Woller J. (1957): Firearm Investigation, Identification and Evidence T.C. Samsworth (Ed.), The Stackpole Company, Harrisburg, Penn sylvania Stackpole. pp. 283.

28. Jauhan M. and Bandopadhya A. (1978): Progress in the Development of Casualty Criteria. Bureau of Police Research and Development Quarter III 78,pp. 22-23.

29. Leong Gregory B. and Silva J. Arthur (1995): A Psychiatric Legal Analysis of Psychotic Criminal Defendants Charged With Murder. J. Forensic Sci. 40 (3): 445-448.

30. Lester David (1992). "Can there be a Durkheimian Theory of Homicide", Indian J. Criminology. $20(2): 2$.

31. Lombroso, Cerare (1911): Criminal Man According to Classification, New York, Putnam.

32. Lowry E.D. (1968): Interior Ballistics. Double Day \& Co. New York, Chapter 1.

33. Luce E. and Griffen W. (1978): Shotgun injuries of the upper extremities. Jr. Trauma Vol. 18. July 78, p. 487.

34. Nabachandra, H. (1984): A Study of Homicide Firearm Injuries in Medicolegal Autopsies. Thesis Submitted for the Degree of Doctor of Medicine (Forensic Medical), Institute of Medical Science, B.H.U., Varanasi. 
35. Nagpaul, H. (1982): An Analysis of Homicide in Community of North India Discussion of Its Major Facets. Indian J. of Criminology. 13(2): 122.

36. Noguchi T. (1972): The Medicolegal Investigation of Homicide: Presentation in Plenary Session of Homicide Investigation, the Second Western Conference on Criminal and Civil Problems, Wichita, Kansas.

37. Roy Kishor Kumar (1994): Study of Medico Legal Aspects of Homicide in Varanasi. M.D. Thesis.

38. Walker J.T. (1940): Bullet Holes and Chemical Residues in Shooting Cases. J. Crim. Law and Criminol. 31:497.

39. Walker J.T. (1949): Further Observations on the Diphenylamine Test for Gun Powder Residue. Internat. Assoc, for Indet. Proceedings, 34'" Annual Conventional pp. 187.

40. Wani A.K. (1969): Casualty Criteria for Firearm Wounds with Special Reference to Shot Penetration. Jr. Foren. Sci. 14:120.

41. Wecht Cyril H. and Smith R.P. (1974): Medical Evidence in the Assassination of President John F. Kennedy. Legal Medicine Annual, Appleton-Century Crofts.

42. Weinstock, Warner (1979): Committee Report Submitted by Chairman, The Committee of Medicine and Law, Association of the Bar of the City of New York: The International Journal of Medicine and Law. 1(2):181-186.

43. Whelen Col. T. (1946): Small Arms Design and Ballistics, Vol. II, Small Arms Technical Publishing Company, South California U.S.A., Chapter VIII, pp. 136-139.

44. Wilhelm, Russell M. (1973): General Consideration of Firearms Identification and Ballistics in Medicolegal Investigation of Death Edited by Werner U. Spitz and Russell S. Fisher, Charles C. Thomas Publisher, Springfield, Illinois, U.S.A., Chapter IX, pp. 172-183.

45. Wolfgang, M.E. (1958): Pattern in Criminal Homicide. Philadelphia University of Pennsylvania Press, pp. 24-27.

46. Wolfgang, M.E. (1969): Who Kills Whom, Psychology Today. 3(5):54-56.

47. Wolfgang, M.E. (1974) : "Victim Precipitaed Criminal Homicide", Victimology, Drapkin and Viano (Eds.), Lexington Books, Massachusetts, pp. 79-91.

48. Wolfgang, M.E. and Ferracuit, Franco (1967): The Sub-culture of Violence: Towards and Integrated in Criminology, London: Tavistock.

\section{AUTHORS:}

1. Rajeev Kumar

\section{PARTICULARS OF CONTRIBUTORS:}

1. Professor \& Head, Department of Forensic Medicine \& Toxicology, Gold Field Ins titute of Medical Sciences \& Research, Chhainsa, Ballabgarh, Faridabad.

\author{
NAME ADDRESS EMAIL ID OF THE \\ CORRESPONDING AUTHOR: \\ Dr. Rajeev Kumar, \\ Professor \& Head, \\ House No. $-877,2^{\text {nd }}$ Floor, \\ Sector - 40, Gurgaon, PIN - 122001. \\ Email - rajeevkyam@gmail.com
}

Date of Submission: 24/09/2013.

Date of Peer Review: 02/10/2013.

Date of Acceptance: 19/10/2013.

Date of Publishing: 28/10/2013 